\title{
Utjecaj poremećaja iz spektra autizma na obitelj
}

\section{The impact of autism spectrum disorders on the family}

\author{
Radoslav Kosić ${ }^{*}$, Alida Duraković Tatić2 ${ }^{2}$ Daniela Petrićc ${ }^{3}$ Tanja Kosec ${ }^{3}$
}

\begin{abstract}
Sažetak. Poremećaj iz spektra autizma (engl. autism spectrum disorder, ASD) neurorazvojni je poremećaj kojeg obilježavaju kvalitativne anomalije u društvenoj interakciji i u modalitetima komunikacije koje su popraćene ograničenim, ponavljajućim i stereotipnim repertoarom interesa i aktivnosti te nejednolikim intelektualnim razvojem. Uzrok autizma se ne zna. Smatra se kako je riječ o multifaktorijalnom poremećaju, a povezuje se $s$ genetskim i okolišnim čimbenicima. Svrha rada jest dati pregled znanstvene i stručne literature na temu utjecaja djeteta s autizmom na obitelj. Roditelji se moraju suočiti s postavljenom i teško prihvaćenom dijagnozom te je moraju prenijeti ostalim članovima obitelji. Potrebna je prilagodba novom načinu života. Proces prilagodbe, prihvaćanja i privikavanja je dugotrajan, a kod nekih roditelja traje cijeli život. Obitelj poprima novu ulogu, čiji je glavni cilj podizanje djeteta i preuzimanje pune odgovornosti za dijete koje ovisi o angažmanu vlastite obitelji. Uočena je viša stopa razvoda kod roditelja, negativni utjecaji kroničnog stresa i izoliranje iz zajednice. Negativan se utjecaj uočava i kod braće i sestara djece s autizmom. Od izrazite je važnosti edukacija roditelja. Često se roditelji u procesu prihvaćanja počinju educirati i sudjelovati aktivno u grupama podrške i prosvjećivanju zajednice te zagovaranju za svoje dijete.
\end{abstract}

Ključne riječi: autizam; obitelj; stres

Abstract. Autism Spectrum Disorder (ASD) is a neurodevelopmental disorder characterized by qualitative anomalies in social interaction and communication modalities that are accompanied by a limited, repetitive, and stereotypical repertoire of interests and activities and uneven intellectual development. The etiology of autism is unknown. It's considered to be a multifactorial disorder, linked to genetic and environmental factors. The purpose of this paper is to review the available literature on the impact of autism spectrum disorders on the family. Parents must face a set and severely diagnosed diagnosis and must relocate it to other family members. It is necessary to adapt to a new way of life. This process of adaptation, acceptance, and adoption is long-lasting, and in some cases it lasts for a lifetime. The family takes on a new role, whose main goal is to raise a child and assume full responsibility for children dependent on the engagement of their own family. A higher divorce rate was observed in parents, the negative effects of chronic stress and isolation from the community. Negative impacts are also noticed in siblings of autistic children. Of paramount importance is parent education. Often parents in the process of acceptance are beginning to educate and actively participate in community support groups and advocate for their child.

Key words: autism; family; stress
${ }^{1}$ Sveučilište u Rijeci, Fakultet zdravstvenih studija, Katedra za zdravstvenu njegu, Rijeka, Hrvatska

${ }^{2}$ Klinički bolnički centar Rijeka, Hrvatska ${ }^{3}$ Sveučilište u Rijeci, Medicinski fakultet, Katedra za psihijatriju i psihološku medicinu, Rijeka, Hrvatska
*Dopisni autor:

Radoslav Kosić, mag. educ. rehab. Sveučilište u Rijeci, Fakultet zdravstvenih studija, Viktora Cara Emina 5, 51000 Rijeka E-mail: radoslav.kosic@uniri.hr

http://hrcak.srce.hr/medicina 


\section{UVOD}

Poremećaj iz spektra autizma (engl. autism spectrum disorder, ASD) karakteriziran je širokim spektrom kliničkih značajki koje mogu znatno varirati od pojedinca do pojedinca u težini i varijabilnosti kliničke slike. Promjene koje se javljaju uključuju poremećaje govora, poremećenu socijalnu interakciju, ponavljajuće radnje i poremećaje komunikacije. Prevalencija poremećaja iz autističnog spektra porasla je uslijed novih dija-

Djetetova dijagnoza za roditelja predstavlja emocionalnu traumu. Roditelji djece $s$ autizmom imaju veći rizik obolijevanja od bolesti poput depresije i anksioznosti. Spoj smanjene socijalne podrške i oslanjanja na vlastiti odnos predstavlja opasnost za održanje kvalitetnog bračnog odnosa. Partneri se često nađu pod teretom emocionalnih briga i stresa, pa brak i obiteljski život počnu doživljavati kao neugodno iskustvo. Uključivanje očeva od izrazite je važnosti kako bi bili motivirani ostati dio obiteljske zajednice.

gnostičkih kriterija pa se smatra kako poremećaj iz autističnog spektra ima jedno od 68 do 100 djece, ovisno o literaturi. Oko $68 \%$ djece ima određeni stupanj intelektualne nesposobnosti, dok $75 \%$ njih zahtijeva cjeloživotnu društvenu i obrazovnu potporu ${ }^{1}$. U Hrvatskoj se vodi Registar za osobe s invaliditetom u kojem je zabilježeno 2508 osoba koje imaju dijagnozu poremećaja iz spektra autizma².

Briga za dijete s ASD-om predstavlja izazov i zahtijeva mnogo vremena, strpljenja i uloženog truda. Parovi koji imaju dijete s ASD-om moraju biti izrazito prilagodljivi prilikom suočavanja s jedinstvenim roditeljskim zahtjevima ${ }^{3}$. Autistično dijete pokazuje brojne društvene i komunikacijske poremećaje, restriktivno i ponavljajuće ponašanje te ima poteškoće sa spavanjem, što stvara dodatan pritisak na roditelje ${ }^{4}$. Osim toga, visoki troškovi zdravstvene zaštite mogu dovesti do dodatnog financijskog stresa ${ }^{5}$. Posljedično, roditelji djece $s$ autizmom nose se $s$ povećanim razinama stre$s a^{6,7}$, što osim utjecaja na brak ima i negativan utjecaj na dijete i njegov zdravstveni status ${ }^{8}$. Pri tome se kod mnogih parova znaju javiti zanema- rivanje partnera i problemi u odnosu zbog preokupacije bolesnim djetetom ${ }^{8,9}$.

U takvoj obiteljskoj zajednici negativne emocije doživljavaju i ostali članovi, naročito braća i sestre djeteta s autizmom ${ }^{10}$.

Pristup djetetu S ASD-om treba biti multidisciplinaran, što podrazumijeva suradnju brojnih stručnjaka iz različitih područja medicine. Od posebnog je značenja edukacija roditelja, koja pokazuje mnoge prednosti, kako za dijete s autizmom tako i za cijelu obitelj ${ }^{11}$. U Republici Hrvatskoj je pitanje djece s ASD-om i njihovih obitelji prilično marginalizirano. Ne ulažu se dovoljna sredstva i nema sluha za potrebe djeteta i obitelji, čime dolazi do dodatne izolacije obitelji i otežanih uvjeta života ${ }^{12}$. O važnosti autizma, rane dijagnostike i povećanja svjesnosti o autizmu govori i činjenica da je 2. travnja proglašen Svjetskim danom svjesnosti o autizmu ${ }^{13}$.

\section{NAČINI NOŠENJA RODITELJA S DIJAGNOZOM ASD-A KOD DJETETA}

Uobičajeno je da se kod roditelja javi snažna emocionalna reakcija nakon što se njihovom djetetu postavi dijagnoza ASD-a te im je potrebna podrška i pomoć kako bi se prilagodili novonastaloj situaciji i uspjeli odgovoriti najbolje moguće potrebama djeteta ${ }^{14}$. Roditelj suočen s dijagnozom djeteta suočava se istovremeno i sa svojim, ali i društvenim očekivanjima djeteta da ispuni očekivanja u društvenom i emocionalnom razvoju, što kod roditelja može izazvati tugu i žalovanje. To se žalovanje može usporediti s osjećajem gubitka djeteta kod određenog broja roditelja, dok se drugi susreću sa žalovanjem ni ne znajući za čime točno žale $e^{15}$.

Roditelji se moraju suočiti s postavljenom i teško prihvaćenom dijagnozom te je moraju prenijeti ostalim članovima obitelji. Potrebna je prilagodba novom načinu života koji obuhvaća liječničke kontrole, preglede, psihološke, pedagoške i logopedske procjene i procese savjetovanja i terapije. Taj proces prilagodbe, prihvaćanja i privikavanja je dugotrajan, a kod nekih roditelja traje cijeli ži$\operatorname{vot}^{16}$.

Karakteristično je da gotovo svi roditelji u detalje pamte dan kad su saznali da im dijete ima autizam. Pamte tko i na koji način im je prenio vijest, 
što su odjenuli, koje je bilo doba dana, kakva je melodija svirala u pozadini i slično. Riječ je o takozvanom „blitz“ pamćenju karakterističnom za visokoemotivan događaj koji se može usporediti s emocionalnom traumom. Prema tome, djetetova dijagnoza za roditelja predstavlja emocionalnu traumu $^{17}$. Roditelji djeteta s autizmom nemaju taj luksuz da se bave svojom emocionalnošću i emocijama jer su potrebe djeteta iznimno velike ${ }^{16}$. Moraju biti i roditelji i terapeuti svom djetetu uvijek nasmijani, dobre volje, staloženi. Ako napredak djeteta ne ide očekivano, često se trebaju nositi s pitanjima okoline - trude li se dovoljno, a nerijetko bivaju kritizirani od okoline jer se često djecu s autizmom doživljava kao neodgojenu i djecu nepoželjnog ponašanja ${ }^{16}$. Dijete $s$ autizmom prvenstveno je različito, prema tome i roditeljstvo je različito od prosječnog roditeljstva, a različitost postaje dio obiteljskog identiteta ${ }^{18}$. Kod roditelja se redovito budi osjećaj krivnje. Neki roditelji eksternaliziraju osjećaj tražeći uzroke u vanjskim čimbenicima poput hrane, lijekova ili svađe u obitelji. Prvi korak, ujedno i najvažniji u procesu prihvaćanja jest rješavanje osjećaja krivnje. Prihvaćanje vlastitih emocija (ljutnja, osjećaj beznadnosti, tuga, želja za odustajanjem...) drugi je korak. Naposljetku, roditelj ne smije zanemariti sebe $^{16}$. Unatoč tome što briga o djetetu s autizmom zahtijeva požrtvovnost i puno izdvojenog vremena za dijete, roditelj mora izdvojiti vrijeme za sebe i svoje potrebe ${ }^{19}$.

\section{UTJECAJ AUTISTIČNOG DJETETA NA}

$$
\text { RODITELJE }
$$

Utjecaj podizanja djeteta s autizmom na roditelje dobiva sve veću pozornost. Unatoč širokom spektru i različitom intenzitetu simptoma, većina djece pokazuje simptome otežane komunikacije, ima otežanu socijalnu interakciju, otežane i rigidne obrasce ponašanja, ograničene interese i reduciranu aktivnost ${ }^{8}$.

Simptomi autizma najčešće se počnu javljati u ranom razvojnom periodu djeteta i značajno utječu na dijete i članove obitelji. Obitelj poprima novu ulogu, čiji je glavni cilj podizanje djeteta i preuzimanje pune odgovornosti za dijete koje ovisi o angažmanu vlastite obitelji. Život $s$ autističnim djetetom ima jak utjecaj na obiteljsku zajednicu jer se oba roditelja moraju naučiti prilagoditi potrebama djeteta ${ }^{17}$. Prema procjenama, $85 \%$ osoba s autizmom nikad ne dostigne prag samostalnosti za život bez nečije pomoći. Posljedično tome, uloga aktivnog roditeljstva znatno je prolongirana, čime raste razina stresa i dolazi do mijenjanja kretanja kroz normalne faze životnog ciklusa $^{4,16}$. Prema tome i uloga se roditelja mijenja i postaje izazov nositi se s takvim životnim okolnostima ${ }^{17}$. Roditelji se trebaju naučiti nositi s odgovornošću koju sa sobom nosi odgoj djeteta koje je u velikoj mjeri ovisno o njima, trebaju se pobrinuti o adekvatnoj prehrani, sigurnosti, organizaciji odgojno-obrazovnog programa i programa rane intervencije te formiranju adekvatnih $i$ ugodnih odnosa djeteta s članovima obitelji i drugim ljudima s kojima dijete dolazi u kontakt ${ }^{8,20}$.

Roditelji djece $s$ autizmom više brinu o tome hoće li njihovo dijete ikada imati život barem približan onome kakav imaju djeca normalnog razvoja, za razliku od roditelja koji imaju dijete $s$ kroničnom tjelesnom bolešću ${ }^{21}$. Zanimljivo je kako unatoč tome roditelji koji imaju dijete $s$ razvojnim poremećajem, imaju znatno pozitivnije viđenje toga koliko vremena i truda treba za brigu o djetetu u odnosu na skupinu roditelja s tjelesno bolesnim djetetom. Također, imaju bolje viđenje utjecaja bolesti na cjelokupan obiteljski život i na članove obitelji22.

Rejani i Ting (2015.) u istraživanju kojeg su proveli, dobili su rezultate koji pokazuju da roditelji djece $s$ autizmom imaju veći rizik obolijevanja od bolesti poput depresije i anksioznosti te su skloniji bračnim nesuglasicama od roditelja zdrave dje$\mathrm{ce}^{23}$. Zablotsky i sur. (2014.) u svom istraživanju dobili su podatke da se parovi koji odgajaju dijete s autizmom susreću s povećanim roditeljskim i financijskim zahtjevima, što svaki partner doživljava i proživljava na drugačiji način ${ }^{5}$. McStay i sur. (2014.) ispitivali su kvalitetu života roditelja djece s autizmom i pokazali da zahtjevi koji su postavljeni pred roditelje povećavaju bračno nezadovoljstvo i nezadovoljstvo životom općenito. Partneri se često nađu pod teretom emocionalnih briga i stresa pa brak i obiteljski život počnu doživljavati kao neugodno iskustvo ${ }^{24}$. Das i sur. (2017.) svojim istraživanjem potvrdili su da spoj smanjene socijalne podrške i oslanjanja na vlasti- 
ti odnos predstavlja opasnost za održanje kvalitetnog bračnog odnosa, naročito ako se partneri sa stresom i tugom nose na različit način. Iz tih je razloga zabilježena znatno veća stopa razvoda ${ }^{16}$. Istraživanje koje su proveli Pozo i sur. (2013.) pokazalo je kako je incidencija razvoda partnera koji imaju dijete s autizmom veća $(23,5 \%)$, nego partnera koji imaju zdravu djecu (13,8\%). Povećanu incidenciju razvoda tumače povećanom razinom stresa, koja dovodi do veće stope nezadovoljstva bračnim odnosom ${ }^{25}$. S druge strane, Freedman i sur. (2012.) proveli su istraživanje na primjeru od 900 parova s djecom koja imaju poremećaj iz autističnog spektra i nisu uspjeli dokazati tezu kako je veća stopa razvoda među parovima s autističnim djetetom ${ }^{38}$. Unatoč tome, Lee i sur. (2017.) u svojem istraživanju dobili su rezultate koji pokazuju kako je stupanj emocionalnog nezadovoljstva znatno viši, a veće je i psihičko opterećenje u obiteljima čiji je član dijete s autizmom ${ }^{8}$.

\section{Utjecaj postavljene dijagnoze autizma na majke}

Tomeny (2017.) je u svojem istraživanju dobio da je viša razina izraženosti simptoma ASD-a kod djeteta pozitivno povezana s porastom poteškoća koje majke pokazuju prilikom postavljanja dijagnoze (viša razina roditeljskog stresa, tuga, strah, bespomoćnost). Ovaj rezultat sugerira da majke koje s većim intenzitetom percipiraju simptome autizma u svoje djece, teže smanjenju svojih strategija suočavanja s problemom, misle da ne mogu dovoljno dobro prenijeti svoje osjećaje drugima te da prema drugima pokazuju manje brige i empatije ${ }^{26}$. Istraživanje koje su proveli Yorke i sur. (2018.) ukazuje da socijalna podrška ima puferski učinak na suočavanje sa stresom koji majke doživljavaju postavljanjem dijagnoze ${ }^{27}$. U svojem istraživanju Lindsey i Barry (2018.) dobili su da osjetljivost majčinog suočavanja s djetetovom dijagnozom ovisi o tome koristi li pozitivne ili negativne strategije suočavanja, odnosno da majke koje koriste strategije kao što su distanciranje i/ili poricanje kasnije imaju više poteškoća s mentalnim zdravljem ${ }^{28}$. Bauminger i sur. (2010.) pokazali su da ozbiljnost problema u ponašanju djeteta S ASD-om, neovisno o njegovom kognitivnom razvoju, zahtijeva izvanredne resurse koji, ako ih majka ne koristi ili ih ne može koristiti, stvaraju veću razinu roditeljskog stresa kod maj- $\mathrm{ki}^{29}$. Smith i sur. (2008.) u svojem radu naglašavaju da su načini suočavanja koji su usredotočeni na problem, povezani s većom dobrobiti, djeluju kao štit kod majki čija su djeca pokazivala visoki stupanj simptoma autizma ${ }^{30}$. Longitudinalna studija koju su proveli Zaidman-Zait i sur. (2017.) pokazala je da se dugotrajni stres koji doživljavaju majke djece s ASD-om pogoršava kad su osobni i socijalni resursi nedovoljni. Majke koje su koristile pozitivne strategije suočavanja, bilo u vrijeme postavljanja dijagnoze ili protokom vremena, imale su niže razine roditeljskog stresa ${ }^{31}$. Miranda i sur. (2019.) u svojem istraživanju navode da pojačan majčin angažman u slučajevima kada su djetetovi simptomi teži, ima negativan učinak na majčinu dobrobit. Vjerojatno je da djetetove poteškoće u ponašanju pridonose umoru majke, što zauzvrat može utjecati na uporabu neučinkovitih strategija suočavanja i povećati stres. Nepredvidivi zahtjevi i promjene u djetetovom ponašanju stvaraju u majki stalnu zabrinutost zbog straha hoće li ili neće odgovarajuće reagirati na zahtjeve djeteta i istovremeno održati obiteljsku ravnotežu, što stvara fizički i mentalni umor koji povećava stres $^{32}$. Boyd (2002.) naglašava da više od $50 \%$ majki navodi smanjenu sposobnost uživanja u životu jer se suočavaju s izazovima povezanim s odgojem djeteta s ASD-om. Zapravo je niska razina socijalne potpore identificirana kao najsnažniji prediktor depresije i tjeskobe kod majki ${ }^{33}$. Pozo i Sarriá (2014.) u svojem su istraživanju dobili da socijalna podrška igra važnu zaštitnu ulogu protiv stresa, posebno za majke ${ }^{34}$. Al-Kandari i sur. (2017.) u svojem istraživanju pokazali su da na smanjenje stresa kod majki značajno utječe primljena podrška od obitelji i društvenih skupina, kao i sposobnosti majki da uživaju u životu ${ }^{35}$. Pozo i Sarriá (2014.) ukazuju da i za očeve i za majke težina poremećaja i problemi u ponašanju djeteta s ASD-om imaju izravan i pozitivan učinak na stres ${ }^{34}$.

\section{Utjecaj postavljene dijagnoze autizma na očeve}

Iskustvo koje prolaze očevi nakon postavljanja dijagnoze autizma je poprilično neistraženo. $U$ jednom od rijetkih istraživanja koje su na tu temu proveli Burell i sur. (2017.) utvrđeno je kako očevi kad saznaju dijagnozu, većinom reagiraju osjećajem tuge i straha, najviše u vezi s dugoročnim utjecajem dijagnoze na život njihova djeteta 
(osjećaj gubitka zbog životnih događaja koje njihovo dijete nikad neće doživjeti) ${ }^{36}$. Ostala su istraživanja u visokom postotku istraživala dojmove majki ili spol roditelja nije bio važan za samo istraživanje. $U$ obiteljima $s$ autističnim djetetom uglavnom su očevi oni koji rade, dok su majke kod kuće s djecom pa su pristupačnije za istraživanje i sl. Samim time manje su poznati stavovi, razmišljanja i doživljaj cjelokupne situacije iz percepcije očeva ${ }^{36}$.

Burell i sur. (2017.) u svom istraživanju dobili su rezultate koji ukazuju na nedostatak inkluzije u procesu postavljanja dijagnoze, a to je ozbiljan problem s kojim se susreću očevi. Šest od deset očeva ima osjećaj kako nisu imali adekvatnu potporu u tom razdoblju. Takvi podatci ukazuju na propuste u pristupu jer se većina programa podrške usmjerava na majke ${ }^{36}$. Potter (2017.) naglašava da je uključivanje očeva od izrazite važnosti kako bi bili motivirani ostati dio obiteljske zajednice, s obzirom na činjenicu da tako stresno iskustvo predstavlja izazov za održavanje zajedništva u obitelji, kratkoročno i dugoročno ${ }^{37}$.

Freedman i sur. (2012.) navode da je nedostatno informiranje nakon postavljanja dijagnoze autizma kod djeteta ključna briga kod očeva. Dobivanje točnih informacija o prirodi poremećaja, kao i o dostupnim metodama liječenja, terapijskim pristupima i grupama podrške od izrazite je važnosti u vrijeme neposredno nakon postavljanja dijagnoze $^{38}$. Das i sur. (2017.) nakon provedenog istraživanja (budući da danas $99 \%$ kućanstava ima pristup internetu) predlažu razvoj ciljanih mrežnih izvora informacija, senzitivno prilagođenih kako bi zadovoljili hitne i specifične zahtjeve roditelja koji su se nedavno susreli s dijagnozom autizma ${ }^{16}$. Potter (2017.) potvrđuje da je takav pristup naročito dobar za očeve s obzirom na to da informaciji mogu pristupiti u bilo koje doba dana tijekom radnog tjedna, kao i za one očeve kojima je draži ovakav pristup nego licem u lice (engl. face to face) ${ }^{37}$.

\section{UTJECAJ ŽIVOTA S AUTISTIČNIM DJETETOM NA BRAĆU I SESTRE}

Kako je broj djece s dijagnozom autizma u neprestanom porastu, tako raste i broj njihove braće i sestara koji se moraju s time nositi. Karakteristike i izazovi u razvoju djeteta s autizmom, poput sen- zorne osjetljivosti, ponavljajućih stereotipnih radnji, otežane socijalne interakcije i komunikacije zahtijevaju prilagodbu cijele obitelji, pa tako i braće i sestara ${ }^{16}$. Danas postoji malo istraživanja o doživljajima i perspektivi djece normalnog razvoja koja žive u zajednici s autističnim djetetom jer je fokus istraživanja uglavnom usmjeren na samo dijete s autizmom ili na roditelje ${ }^{39}$. Meyer i sur. (2011.) u svojem istraživanja pokazali su kako je cjelokupno iskustvo života s bratom ili sestrom $s$ autizmom prilično negativno. Dijete koje se normalno razvija, često ima osjećaj zapostavljenosti jer je sva pažnja i briga usmjerena na dijete $s$ autizmom $^{40}$. Ross i Cushelly (2006.) proveli su istraživanje čiji rezultati ukazuju da agresivno ponašanje, uključujući fizičko i verbalno te nepredvidiva priroda djeteta $s$ autizmom kod djeteta $s$ normalnim razvojem dovode do trajnog osjećaja anksioznosti, pritiska i nestabilnosti. To je naročito izraženo kod adolescenata, koji osim što se moraju nositi s promjenama normalnim za adolescenciju, moraju se znati nositi i s bratom ili sestrom s autizmom ${ }^{41}$. Adolescencija kao razvojna faza inkorporira fizičko i psihičko sazrijevanje. Pod psihičkim sazrijevanjem misli se na uspostavljanje osjećaja vlastitog identiteta, stjecanje novih kognitivnih sposobnosti, razvijanje morala te doživljavanje novih društvenih zahtjeva i tranzicija prema ulogama odraslog pojedinca. Orsmond i sur. (2009.) izvještavaju da adolescenti često osjećaju nelagodu i sram na javnim mjestima i prilikom socijalnih interakcija. Negativne reakcije na njihovog brata ili sestru s autizmom, poput osuđivanja, dovode do intenziviranja osjećaja koji su već od ranije aktivni - ljutnje, bijesa, razočaranja i frustriranosti42. Gorjy i sur. (2017.) naglašavaju da manjak razumijevanja za djecu $\mathrm{s}$ autizmom unutar zajednice dovodi do negativnih iskustava kod adolescenta jer ih postavlja u položaj gdje moraju odgovarati na brojna pitanja i nositi se s osuđivanjem okoline i ignoriranjem. Oni koriste niz obrambenih mehanizama kako bi se prilagodili tim negativnim iskustvima. To uključuje odvraćanje pažnje, rješavanje problema, rezignaciju, emocionalnu kontrolu i pomicanje osobnih granica te izolaciju ${ }^{10}$.

U istraživanjima koje su proveli Ross i Cuskelly (2006.) i Orsmond i sur. (2007.) pokazalo se kako 
je za prihvaćanje autističnog brata ili sestre najvažnije suočavanje s novonastalom situacijom. Imati člana obitelji s autizmom ne mora biti nužno negativno iskustvo. Može potaknuti pozitivne emocije i načine ponašanja poput brige za drugoga, jačeg samopoštovanja, suosjećanja i sazrijevanja ${ }^{41,39}$. Orsmond i sur. (2009.) ukazuju na to da su braća i sestre često ponosni na uspjehe i cijene odnos s autističnim bratom ili sestrom. Nerijetko preuzimaju dio odgovornosti i brige na sebe te su uključeni u edukaciju. Znaju se postaviti kao desna ruka svojih roditelja, kao njegovatelji i zaštitnici i ponekad su u tome uspješniji nego roditelji. Utvrđeno je da adolescent koji je detaljno upoznat s autizmom, bolje prihvaća obiteljsku situaciju, a karakteristično je da je prihvaćanje to bolje što je starije životne dobi ${ }^{42}$. Gorjy i sur. (2017.) navode da je roditeljski utjecaj izrazito važan $i$ utječe na formiranje iskustva adolescenta u vezi obiteljske situacije. Neovisno o tome je li njihov doživljaj obiteljske situacije pozitivan ili negativan, svi se slažu kako je život u njihovoj obitelji različit od života obitelji sa zdravom djecom. Uspoređujući djecu koja odrastaju s autističnim bratom ili sestrom s vršnjacima, uočeno je kako su suosjećajniji, tolerantniji te imaju više razumijevanja ${ }^{10}$.

UTJECAJ PONAŠANJA DJETETA S AUTIZMOM NA OBITELJ

Djeca s autizmom često pokazuju različite vrste samostimulirajućeg ponašanja (engl. stimming) poput ljuljanja tijelom ili pljeskanja dlanovima i stereotipnog ponašanja poput fiksiranja pažnje na određene dijelove predmeta (npr. kotači na autiću). Znaju se također nerijetko igrati sa svojim igračkama na stalno isti, ritualiziran način (npr. potreba za slaganjem igračaka na točno određen i nepromjenjiv način). Prisiljavanje djeteta na odstupanje od tih formi može dovesti do napadaja bijesa i drugih agresivnih ponašanja. To dovodi do povećane razine stresa za dijete i roditelje. Djeca s autizmom mogu pokazivati i druga osebujna i/ili štetna ponašanja. Do takvog ponašanja najčešće dolazi ako im se na neki način prekine rutina, stereotipno ponašanje ili im se naruši osjetilni integritet. Ponašanje se može manifestirati kao samoozljeđivanje, neprikladno seksualno ponašanje te ponašanje koje može naštetiti drugima. U svjetlu takvog ponašanja, roditelji mogu doživjeti javnu neugodnost, osuđivanje i odbacivanje od društva koje nije senzibilizirano na takve obrasce ponašanja. Dijete s autizmom se u zajednici prvenstveno doživljava kao neodgojeno i zločesto dijete, a roditelje se doživljava kao loše roditelje koji nisu u stanju izvršiti svoju roditeljsku dužnost ${ }^{15}$. Nerijetko se roditelji osjećaju društveno izolirani, što nastaje kao posljedica neprilagođenog djetetovog ponašanja ustaljenim društvenim normama. S druge strane, roditelji i sami djelomično potaknu izolaciju. Tim obrascem ponašanja dolazi do stvaranja takozvane „autistične obitelji“14.

\section{UTJECAJ AKUMULIRANOG STRESA NA} OBITELJ DJETETA S AUTIZMOM

Freedman i sur. (2012.) utvrdili su kako se razina stresa koju dostižu roditelji djece s autizmom, naročito majke, može usporediti s razinama stresa koju doživljava vojnik za vrijeme rata, što može imati ozbiljan utjecaj na zdravlje ${ }^{38}$. Li i sur. (2018.) u svom su istraživanju dobili kod $34 \%$ roditelja autistične djece visoke razine stresa, a samo kod $2 \%$ roditelja djece $s$ normalnim razvojem ${ }^{9}$. Freedman i sur. (2012.) izvještavaju da je roditeljski stres najsnažniji u vrijeme postavljanja dijagnoze. Otprilike $80 \%$ roditelja u tom se razdoblju nosi s visokim razinama stresa. Utvrđeno je kako naročito stres kod majke dovodi do oslabljenih roditeljskih funkcija, manje uspješnog korištenja dostupnih usluga i uključivanja u zajednicu te slabijeg razvojnog ishoda za dijete ${ }^{38}$. Zand i sur. (2018.) u svojem istraživanju dobili su da osim viših razina stresa, majke se nose i s osjećajem niže razine roditeljske kompetencije prilikom nošenja s ponašanjem djeteta. Djetetovo ponašanje primarni je pretkazatelj majčina stresa i obiteljskog funkcioniranja ${ }^{43}$.

Rayan i Ahmad (2018.) u svojem su radu pokazali kako su stres i nezadovoljstvo kod roditelja to više izraženi što su simptomi autizma kod djeteta više prisutni. Većem su stresu izloženi roditelji koji imaju muško dijete $s$ autizmom i roditelji starije životne dobi ${ }^{44}$.

Guinn i sur. (2016.) naglašavaju da se roditelji djeteta s autizmom češće javljaju obiteljskom liječniku 
zbog boli, somatske simptomatologije i poremećaja psihičkog zdravlja ${ }^{45}$. Li i sur. (2018.) navode da neprestano povišene razine kronično akumuliranog stresa mogu dovesti do brojnih zdravstvenih komplikacija uključujući pretilost, kardiovaskularne bolesti, šećernu bolest, gastrointestinalne tegobe, astmu9. Guinn i sur. (2016.) utvrdili su da je veća incidencija kardiovaskularnih bolesti kod roditelja u pedesetim godinama života, kao i veća incidencija mišićno-skeletnih poremećaja u šezdesetim godinama života. Akumulacija kroničnog stresa dovodi do načina života koji narušava zdravlje (pušenje cigareta, povećan unos alkohola, manjak tjelesne aktivnosti, manjak sna), kojim se također povećava rizik oboljenja, naročito od kardiovaskularnih bolesti ${ }^{45}$.

Li i sur. (2018.) navode da izloženost akutnom ili kroničnom stresu dovodi do promjene neuroendokrinog odgovora organizma (sinteza glukokortikoida), a to dovodi do promjene u apetitu, unosu hrane, tjelesnoj težini i pohrani tjelesne masti. Kronično povišene razine stresa povezuju se s povećanim unosom kalorija, slabijom kvalitetom ishrane, većom vjerojatnosti pretilosti, većim opsegom struka i postotka tjelesne masti ${ }^{9}$.

Rayan i Ahmad (2018.) govore da se nerijetko javlja i pad imuniteta, primjerice - uočeno je kako osobe koje su pod kroničnim stresom imaju niže razine protutijela u krvi, a zabilježene su povišene vrijednosti protuupalnih markera. Zabilježeno je kako se kod roditelja autistične djece češće javljaju infekcije herpes simplex virusom ili EpsteinBarrovim virusom uslijed pada imuniteta ${ }^{44}$. Utjecaj stresa jak je i na mentalno zdravlje pa se često javljaju depresija i anksioznost ${ }^{9,23,38}$. Psihički se poremećaji učestalije javljaju kod majki nego kod očeva ${ }^{38,44}$.

\section{RODITELJSKA KOMPETENCIJA I PONAŠANJE}

$$
\text { DJETETA }
$$

Saznanje kako dijete ima autizam, može dovesti do preispitivanja vlastite roditeljske sposobnosti. Roditeljska je kompetencija multidimenzionalna, građena od bihevioralnih, kognitivnih i afektivnih komponenata. Eikeseth i sur. (2015.) kao srž kognitivnog aspekta roditeljske kompetencije navode roditeljsku efikasnost, odnosno vjerovanje roditelja da je spreman izvršiti roditeljske zadaće ${ }^{4}$. Das i sur. (2017.) u svojem istraživanju pokazali su kako roditeljska efikasnost ima utjecaja na ponašanje roditelja i funkcioniranje djeteta ${ }^{16}$. Freedman i sur. (2012.) u svojem istraživanju utvrdili su da kod većine djece s razvojnim poteškoćama, pa tako i kod djece s autizmom, što je viši stupanj roditeljske efikasnosti, to je zabilježen niži stupanj kažnjavanja djeteta i eksternalizacije negativnog ponašanja djeteta $^{38}$. Također navode pozitivnu povezanost između vjerovanja majke kako je uspješna kao roditelj i aktivnog uključivanja u razvoj djeteta ${ }^{38}$. S

Braća i sestre često su ponosni na uspjehe i cijene odnos s bratom ili sestrom s autizmom. Stres i nezadovoljstvo kod roditelja to su više izraženi što su simptomi autizma kod djeteta više prisutni. Edukacijom roditelja dolazi do znatnog poboljšanja roditeljstva, roditeljskog zadovoljstva i prilagođavanja. Rano prepoznavanje i ciljana intervencija dovode do značajnog poboljšanja ishoda i veće kvalitete života osoba $s$ autizmom i njihovih obitelji.

druge strane, Zand i sur. (2018.) dobili su da je viša razina stresa kod majke imala negativan utjecaj na ponašanje djeteta ${ }^{43}$.

\section{OBITELJSKO FUNKCIONIRANJE I PONAŠANJE} DJETETA

Saznavši za dijagnozu autizma kod djeteta, cijela obitelj mora proći kroz proces prilagodbe. Za te obitelji usklađivanje svakodnevnog života s potrebama djeteta ima utjecaj ne samo na roditeljsku ulogu, već i na smanjenje kvalitete obiteljskog života, kao i na porast stresa ${ }^{46}$. Das i sur. (2017.) izvještavaju da obitelji čiji je član dijete s autizmom pokazuju niži stupanj prilagodljivosti od obitelji čiji je član dijete s drugim poremećajima u razvoju ${ }^{16}$. Kostiukow i sur. (2019.) navode da su članovi obitelji prisiljeni prihvatiti određeno rutinsko ponašanje kako bi zadovoljili stalne potrebe djeteta s autizmom ${ }^{21}$. Xue i sur. (2014.) izvješćuju kako je uobičajeno da se zbog brige i nelagode uslijed nepredvidljivog i često društveno neprihvatljivog ponašanja djeteta, cijela obitelj isključuje iz aktivnosti u zajednici ${ }^{46}$. Zand i sur. (2018.) u svojem istraživanju dobili su rezultate koji govore da promjene $u$ ponašanju djeteta $s$ autizmom češće do- 
vode do stigmatiziranja, osuđivanja i negativnog doživljaja cjelokupne obitelji nego ostali simptomi koji prate autizam. Slijedom toga, poučavanje roditelja strategiji upravljanja, prevenciji i ublažavanju takvog ponašanja može pomoći pri smanjenju negativnih stavova okoline i njihovom utjecaju na obitelj ${ }^{43}$.

\section{EDUKACIJA RODITELJA}

Timmons i Ekas (2018.) u svojem radu naglašavaju da cilj edukacije roditelja jest prevenirati i djelovati na probleme u djetetovu ponašanju putem proširivanja roditeljskog znanja, vještina i samopouzdanja. Roditelje treba podučiti mijenjanju vlastitog ponašanja kako bi se promijenilo i djetetovo ${ }^{47}$. Zand i sur. (2018.) također navode da se edukacijom roditelja dolazi do znatnog poboljšanja roditeljstva, roditeljskog zadovoljstva i prilagođavanja, a time i do prilagođavanja djetetova ponašanja i boljeg funkcioniranja obitelji ${ }^{43}$.

Edukacija roditelja je potrebna jer je autizam cjeloživotni i sveobuhvatni razvojni poremećaj, koji utječe na samo dijete, ali i cijelu obitelj u smislu funkcioniranja, socijalne inkluzije, obrazovnih postignuća i mogućnosti zapošljavanja. Stoga se i razvio termin „autistična obitelj“ koju karakterizira socijalna izolacija12,14,16.

Edukacija roditelja važan je alat u podršci djetetu i cijeloj obitelji jer je karakteristično za autizam da tradicionalne/standardne roditeljske strategije nisu učinkovite ${ }^{12}$.

Prednosti edukacije roditelja:

- bolje razumijevanje vlastitog djeteta

- smanjivanje stresa u obitelji

- smanjenje ovisnosti osobe s autizmom o tuđoj pomoći

- poboljšanje roditeljskih vještina (podrška djetetu prilikom učenja, poboljšanje funkcioniranja obitelji)

- poboljšanje obrazovnog, socijalnog i ekonomskog statusa ${ }^{12}$.

Preece (2015.) u projektu „Edukacija roditelja djece s poremećajem iz spektra autizma u jugoistočnoj Europi“ čiji je voditelj, naglašava da unatoč očitim prednostima edukacije roditelja i tome da je roditelji smatraju korisnom, postoje i određeni problemi poput otežanog pristupa edukaciji zbog osiguravanja brige za dijete, lista čekanja, udaljenosti pružanja adekvatnih tretmana i slično. Problem se javlja i u tome što je većina programa edukacije koja je dostupna putem interneta, namijenjena američkoj i britanskoj populaciji jer se temelji na njihovim modelima, što može biti nedostupno, odnosno neprimjereno korištenju na drugim područjima ${ }^{12}$.

\section{ODNOS RODITELJSKIH OČEKIVANJA} U EDUKACIJI DJETETA S AUTIZMOM

U obiteljima koje imaju djecu normalnog razvoja uobičajeno je da roditelji iznose svoje viđenje i očekivanje budućih uspjeha svoje djece. Odnos između očekivanja i djelovanja proteže se na niz važnih ishoda. Roditelji koji prate i osiguravaju kvalitetnu edukaciju svojoj djeci, očekuju pozitivne rezultate za svoju djecu i vjeruju kako uloga roditelja uključuje i poticanje obrazovnih postignuća. Roditeljsko je očekivanje prediktor roditeljskog djelovanja i edukacijskih ishoda djeteta. Prateći učinak roditeljskog očekivanja na djecu s poremećajem iz autističnog spektra, došlo se do sličnih rezultata. Thomas i sur. (2018.) proučavali su djecu s intelektualnim teškoćama i djecu s poremećajem iz autističnog spektra i utvrdili kako je kod djece s intelektualnim teškoćama čija su roditeljska očekivanja bila visoka, došlo do kontinuiranog školovanja, dok su se djeca roditelja koji su smatrali da obrazovanje njihove djece nema smisla, rjeđe upisivala u škole i imala lošije rezultate. Prateći djecu s poremećajem iz autističnog spektra, utvrđeno je kako visoka roditeljska očekivanja pridonose završetku srednje škole i većoj vjerojatnosti zaposlenja. Zanimljivo je kako veći utjecaj na zaposlenje djeteta ima roditeljsko očekivanje i roditeljski angažman oko edukacije djeteta nego samostalnost u izvršavanju zadataka, komunikacija u društvu i pristup tranzicijskim programima. Veći uspjeh postižu djeca bijele rase, višeg socioekonomskog statusa, s majkama koje imaju visok stupanj obrazovanja ${ }^{48}$.

\section{UTJECAJ RODITELJSKE PSIHOPATOLOGIJE I TEŽINE AUTIZMA NA RODITELJSKA OČEKIVANJA}

U istraživanju koje su proveli Rejani i Ting (2015.) roditeljska se psihopatologija pokazala kao prediktor kratkoročnog i dugoročnog uspjeha djeteta. 
Uočili su negativne utjecaje roditeljske psihopatologije kod podizanja djeteta, uključujući i štetne učinke depresije roditelja u perinatalnom razdoblju. Dobili su povezanost između roditeljske psihopatologije, stila roditeljstva i dječjih psihijatrijskih poremećaja, kao i povezanost majčine depresije s nepovoljnijim dječjim ishodom ${ }^{23}$.

Thomas i sur. (2018.) dokazali su da liječenje roditeljske psihopatologije dovodi do poboljšanja ishoda za djecu. Primjerice, liječenje roditelja koji boluje od depresije znatno poboljšava i mentalno zdravlje djeteta, kao i odnos majke i djeteta ${ }^{48}$.

Djeca s autizmom i u odrasloj dobi često ovise o svojim roditeljima i incidencija psihopatoloških stanja značajno je viša kod roditelja čija djeca imaju autizam, nego kod roditelja koji imaju zdravu djecu ili djecu s drugim teškoćama ${ }^{23}$. Većina roditelja autistične djece navodi kako vjeruju da njihovo emocionalno stanje direktno utječe na emocionalno stanje i pojačanu simptomatologiju autizma kod njihova djeteta ${ }^{5,25}$. Rejani i Ting (2015.) izvijestili su kako majke koje pate od depresije češće prijavljuju pojavu simptoma autizma nego majke koje ne pate od depresije ${ }^{23}$. U nekoliko istraživanja utvrđeno je kako su ozbiljniji simptomi autizma, odnosno njihovo javljanje u izravnoj vezi s roditeljskim stresom, poremećajima raspoloženja (anksioznost, depresija) i roditeljskim preopterećenjem ${ }^{4,16,23}$. Zablotsky i sur. (2014.) izvješćuju da klasični simptomi autizma utječu na obitelj, a ukoliko se jave ozbiljniji simptomi poput samoozljeđivanja ili fizičke agresije, to utječe još više ${ }^{5}$. Luque Salas i sur. (2017.) u svojem istraživanju uočili su da bez obzira na to radi li se o negativnom učinku težine autizma na psihičko stanje roditelja ili roditeljske realnosti, što dijete ima teži stupanj autizma, to su niže razine roditeljskog očekivanja pozitivnih ishoda ${ }^{11}$. Istraživanje koje su proveli Thomas i sur. (2018.) pokazalo je kako razina roditeljske psihopatologije utječe na roditeljska očekivanja, odnosno što je veća roditeljska psihopatologija, to je niže očekivanje ${ }^{48}$. Radi toga autori naglašavaju da je prilikom pružanja skrbi djetetu važno usmjeriti pažnju i na roditelje, naročito majke, te im omogućiti adekvatnu pomoć, poput psihoterapije, grupa potpore ili farmakološke terapije koja može držati simptome pod kontrolom ${ }^{48}$.

\section{ZAKLJUČAK}

Roditelji djeteta s autizmom imaju višu stopu razvoda od roditelja djeteta normalnog razvoja. Među roditeljima djece s autizmom utvrđena je viša incidencija anksioznosti, depresije i stresa nego kod roditelja djece normalnog razvoja. Akumuliranje kroničnog stresa dovodi do psihofizičkih poremećaja - kod roditelja djece s autizmom zabilježena je veća incidencija kardiovaskularnih bolesti, mišićnoskeletnih poremećaja, sklonosti rizičnim ponašanjima (pušenje cigareta, pijenje alkohola, pretilost, manjak sna i tjelesne aktivnosti). Odgajanje djeteta s autizmom, uključujući nošenje s bihevioralnim, funkcionalnim i emocionalnim problemima, izrazito je kompleksno i utječe na sve članove obitelji. Braća i sestre često doživljavaju negativna iskustva, ali, s druge strane, većina braće i sestara ranije sazrijevaju, suosjećajniji su, tolerantniji i imaju više razumijevanja. Anksioznost, depresija i razine stresa više su kod majki nego kod očeva. Roditelji koji imaju dijete s razvojnim poremećajem više brinu o tome hoće li njihovo dijete imati život bar približan onom djece s normalnim razvojem, za razliku od roditelja koji imaju dijete koje boluje od neke kronične tjelesne bolesti. Roditeljska psihopatologija (kronični stres, depresija, anksioznost) pokazala se kao pretkazatelj kratkoročnog i dugoročnog uspjeha djeteta. Ona je to jača što je ozbiljniji stupanj autizma kod djeteta. Roditeljska očekivanja manja su što je psihopatologija izraženija, a time opada i uspjeh djeteta. Potpora okoline pomaže u povećanju stupnja samostalnosti osobe s autizmom. Na konačan ishod, osim zdravstvenih djelatnika, utjecaj imaju roditelji, stoga je od iznimne važnosti educirati ih kako bi bili aktivni sudionici u procesu. Rano prepoznavanje $i$ ciljana intervencija dovode do značajnog poboljšanja ishoda i veće kvalitete života osoba s autizmom i njihovih obitelji. Edukacija unutar zajednice od izrazite je važnosti kako bi se povećala svijest o autizmu i kako bi se djeca što lakše asimilirala u zajednicu, a posljedično poboljšala kvaliteta života cijele obitelji.

Izjava o sukobu interesa: Autori izjavljuju kako ne postoji sukob interesa. 


\section{LITERATURA}

1. Pendergrass S, Girirajan S, Selleck S. Uncovering the etiology of autism spectrum disorders: genomics, bioinformatics, environment, data collection and exploration, and future possibilities. Pac Symp Biocomput [Internet]. 2014;422-6. [cited 2020 Aug 15]. Available from: https:// www.ncbi.nlm.nih.gov/pmc/articles/PMC3999434/.

2. Hrvatski zavod za javno zdravstvo, Registar za osobe $\mathrm{s}$ invaliditetom [Internet]. [cited 2020 Aug 15]. Available from: https://www.hzjz.hr/periodicne-publikacije/ izvjesce-o-osobama-s-invaliditetom-u-republicihrvatskoj-stanje-05-2019/.

3. Dardas LA, Ahmad MM. Quality of life among parents of children with autistic disorder: A sample from the Arab world. Res Dev Disabil 2014;35:278-87.

4. Eikeseth S, Klintwall L, Hayward D, Gale C. Stress in parents of children with autism participating in early and intensive behavioral intervention. Eur J Behav Anal 2015;16:112-20.

5. Zablotsky B, Kalb LG, Freedman B, Vasa R, Stuart EA. Health care experiences and perceived financial impact among families of children with an autism spectrum disorder. Psychol Serv 2014;65:395-98.

6. Rivard M, Terroux A, Parent-Boursier C, Mercier C. Determinants of stress in parents of children with autism spectrum disorders. J Autism Dev Disord 2014;44:1609-20.

7. Pisula E, Porębowicz-Dörsmann A. Family functioning, parenting stress and quality of life in mothers and fathers of Polish children with high functioning autism or Asperger syndrome. PloS One [Internet]. 2017;12: e0186536. [cited 2020 Aug 16]. Available from: https:// pubmed.ncbi.nlm.nih.gov/29036188/.

8. Lee AN, Furrow LJ, Bradley AB. Emotionally focused couple therapy for parents raising a child with an autism spectrum disorder: a pilot study. J Marital Fam Ther 2017;43(4): 662-73.

9. Li SX, Pinto-Martin AJ, Thompson A, Chittams J, Kral EVT. Weight status, diet quality, perceived stress, and functional health of caregivers of children with autism spectrum disorder. J Spec Pediatr Nurs [Internet]. 2018;23:e12205. [cited 2020 Aug 16]. Available from: https://pubmed.ncbi.nlm.nih.gov/29240304/.

10. Gorjy SR, Fielding A, Falkmer M. "It's better than it used to be": Perspectives of adolescent siblings of children with an autism spectrum condition. Child Fam Soc Work 2017;22:1488-96.

11. Luque Salas B, Yáñez Rodríguez V, Tabernero Urbieta C, Cuadrado $E$. The role of coping strategies and selfefficacy as predictors of life satisfaction in a sample of parents of children with autism spectrum disorder. Psicothema 2017;29:55-60.

12. Preece D. Edukacija roditelja djece s poremećajem iz spektra s autizmom u Jugoistočnoj Europi [Internet]. Uvod u ESIPP projekt, 2015. [cited 2020 Aug 16]. Available from: http://esipp.eu/wp-content/uploads/2017/04/ ESIPP-What-has-happened-so-far-DP-Cro.pdf.

13. SUZAH [Internet]. Savez udruga za autizam. [cited 2020 Aug 17]. Available from: http://www.autizam-suzah.hr/.

14. Boshoff K, Gibbs D, Phillips LR, Wiles L, Porter L. Parents' voices: "Our process of advocating for our child with autism." A meta-synthesis of parents' perspectives. Child Care Health Dev 2018;44:147-60.
15. Johnson J, Piercy PF. Exploring partner intimacy among couples raising children on the autism spectrum: a grounded theory investigation. J Marital Fam Ther 2017; 43:644-61.

16. Das S, Das B, Nath K, Dutta A, Bora P, Hazarika M. Impact of stress, coping, social support, and resilience of families having children with autism: A North East Indiabased study. Asian J Psychiatry 2017;28:133-9.

17. Lai WW, Goh TJ, Oei TPS, Sung M. Coping and well-being in parents of children with autism spectrum disorders (ASD). J Autism Dev Disord 2015;45:2582-93.

18. Chong WH, Kua SM. Parenting self-efficacy beliefs in parents of children with autism: perspectives from Singapore. Am J Orthopsychiatr 2016;87:365-75.

19. Bonačić $M$. Za autizam - jednaki u različitosti. [Internet] [cited 2020 Aug 17]. Available from: https://autizam. net/2017/01/11/maja-bonacic-razlicite-obitelji/.

20. Hsu YC, Tsai SL, Hsieh MH, Jenks SM, Tsai CH, Hsu MT. On My Own: A Qualitative Phenomenological Study of Mothers of Young Children with Autism Spectrum Disorder in Taiwan. J Appl Res Intellect Disabil 2017; 30:147-56.

21. Kostiukow A, Strzelecki W, Poniewierski P, Samborski W. The estimation of the funtioning of families with ASD children. AIMS Public Health [Internet]. 2019;6:587-99. [cited 2020 Aug 20]. Available from: https://www.researchgate.net/publication/338078858_The_estimation_of_the_functioning_of_families_with_ASD_children.

22. Riper VM, Knafl JG, Roscigno C. Family management of childhood chronic conditions: Does it make a difference if the child has an intellectual disability?. Am J Med Genet 2018;176:82-91.

23. Rejani TG, Ting M. Depression and anxiety among parents with autistic children. J Psychosoc Res 2015;10: 385-91.

24. McStay R, Trembath D, Dissanayake C. Stress and family quality of life in parents of children with autism spectrum disorder: Parent gender and the Double $A B C X$ Model. J Autism Dev Disord 2014;44:3101-18.

25. Pozo P, SarriâA E, Brioso A. Family quality of life and psychological well-being in parents of children with autism spectrum disorders: A Double ABCX model. J Intellect Disabil Res 2013;58:442-58.

26. Tomeny TS. Parenting stress as an indirect pathway to mental health concerns among mothers of children with autism spectrum disorder. Autism 2017;21:907-11.

27. Yorke E, Pippa W, Weston A, Rafla M, Charman T, Simonoff $E$. The association between emotional and behavioral problems in children with autism spectrum disorder and psychological distress in their parents: a systematic review and meta-analysis. J Autism Dev Disord 2018;48:3393-415.

28. Lindsey RA, Barry TD. Protective factors against distress for caregivers of a child with autism spectrum disorder. J Autism Dev Disord 2018;48:1092-107.

29. Bauminger N, Solomon M, Rogers SJ. Externalizing and internalizing behaviors in ASD. Autism Res. 2010;3: 101-12.

30. Smith LE, Seltzer MM, Tager-Flusberg H, Greenberg JS, Carter AS. A comparative analysis of well-being and coping among mothers of toddlers and mothers of adolescents with ASD. J Autism Dev Disord 2008;38:876-89. 
31. Zaidman-Zait A, Mirenda P, Duku E, Vaillancourt T, Smith IM., Szatmari $P$ et al. Impact of personal and social resources on parenting stress in mothers of children with autism spectrum disorder. Autism 2017;21:155-66.

32. Miranda A, Berenguer C, Alvaro M, Rosello B, Baixauli I. Parenting Stress in Mothers of Children With Autism Without Intellectual Disability. Mediation of Behavioral Problems and Coping Strategies. Front Psychol [Internet]. 2019;10:e464. [cited 2020 Nov 25]. Available from: https://www.ncbi.nlm.nih.gov/pmc/issues/327974/.

33. Boyd BA. Examining the relationship between stress and lack of social support in mothers of children with autism. Focus Autism Dev Dis 2020;17;208-15.

34. Pozo P, Sarriá E. A global model of stress in parents of children with autism spectrum disorders (ASD). An Psicol 2014;30:180-91.

35. Al-Kandari S, Alsalem A, Abohalmed S, Al-Orf F, Al-Zoubi $\mathrm{M}, \mathrm{Al}-\mathrm{Sabah} \mathrm{R}$ et al. Brief report: social support and coping strategies of mothers of children suffering from ASD in Kuwait. J Autism Dev Disord 2017;47:3311-19.

36. Burrell A, Ives J, Unwin $G$. The experiences of fathers who have offspring with autism spectrum disorder. J Autism Dev Disord 2017;47:1135-47.

37. Potter AC. "I received a leaflet and that is all": Father experiences of a diagnosis of autism. Br J Learn Disabil 2017;45:95-105.

38. Freedman BH, Kalb LG, Zablotsky B, Stuart EA. Relationship status among parents of children with autism spectrum disorders: a population-based study. J Autism Dev Disord 2012;42:539-48.

39. Orsmond GI, Seltzer M. Siblings of individuals with autism spectrum disorders across the life course. Ment Retard Dev D [Internet]. 2007;13(4):313-20. [cited 2020 Aug 19]. Available from: https://doi.org/10.1002/mrdd.20171.

40. Meyer KA, Ingersoll B, Hambrick DZ. Factors influencing adjustment in siblings of children with autism spectrum disorders. Res Autism Spect Dis [Internet]. 2011;5:141320. [cited 2020 Aug 20]. Available from: http://dx.doi. org/10.1016/j.rasd.2011.01.027.

41. Ross P, Cuskelly M. Adjustment, sibling problems and coping strategies of brothers and sisters of children with autistic spectrum disorder. J Intellect Dev Dis [Internet]. 2006;31:77-86. [cited 2020 19]. Available from: https:// doi.org/10.1080/13668250600710864.

42. Orsmond $\mathrm{Gl}$, Kuo H, Seltzer M. Siblings of individuals with an autism spectrum disorder: Sibling relationships and wellbeing in adolescence and adulthood. Int J Res Pract [Internet]. 2009;13:59-80. [cited 2020 Aug 21]. Available from: https://doi.org/10.1177/1362361308097119.

43. Zand HD, Bultas WM, McMillin ES, Halloran D, White T, McNamara D et al. A Pilot of a Brief Positive Parenting Program on Children Newly Diagnosed with Autism Spectrum Disorder. Fam Process 2018;176:82-91.

44. Rayan A, Ahmad M. Psychological Distress in Jordanian Parents of Children with Autism Spectrum Disorder: The Role of Trait Mindfulness. Perspect Psychiatr C 2018; 54(1):11-8.

45. Guinn JP, Estrela C, Desmaris K, Barker TE. The Impact of Formal and Informal Support on Health in the Context of Caregiving Stress. Fam Relat 2016;65:191-206.

46. Xue J, Ooh J, Magiati I. Family functioning in Asian families raising children with autism spectrum disorders: the role of capabilities and positive meanings. J Intellect Disabil Res 2014;58:406-20.

47. Timmons L, Ekas NV. Giving thanks: Finding from a gratitude intervention with mothers of children with autism spectrum disorder. Res Aut Spect Disord 2018; 49:13-24.

48. Thomas AP, King SJ, Mendelsom LJ, O Nelson-Gray R. Parental psychopathology and expectations for the futures of children with autism spectrum disorder. J Appl Res Intellect Disabil 2018;31:98-105. 